\title{
EPIZOOTICAL CHARACTERISTICS OF AUJESZKY'S DISEASE IN VOJVODINA REGION AND BIOSECURITY CONCERNES
}

\section{Pušić, J. Prodanov-Radulović, R. Došen, I. Stojanov, D. Stojanović, T. Petrović}

Scientific Veterinary Institute «Novi Sad», Rumenacki put 20, 21000 Novi Sad, Republic of Serbia Corresponding author: ivan@niv.ns.ac.rs

Original scientific paper

\begin{abstract}
Aujeszky's disease (Morbus Aujeszky, pseudorabies) is an acute, contagious viral disease, of wide range of domestic and wild-life species. Morbus Aujeszky (MA) is considered as one of the most important infectious diseases, that affect swine production and became a discriminatory factor at the international pig market. The infection in all other animal species except pigs is acute in course and inevitably fatal. The data for this research were taken from several different sources: Epizootiological Reports of Ministry of Agriculture, Forestry and Water Management, Statistical Year Book of Serbia. Also, historical, clinical and epizootiological data were obtained through questionnaire that was sent to farm owners, practicing veterinarians, veterinary inspectors and regional epizootiologists. Significant information were collected through direct epizootical surveillance on the field that encompassed anamnestic, clinical and pathological investigation as well as laboratory diagnostic by virus isolation and serological testing. The purpose of this investigation was to estimate epizootical status of Vojvodina Province concerning MA occurrence in different domestic and wild life species, the possible routes of infection and spreading the disease. The role of various biosecurity measures in prevention and control of MA outbreaks was also studied. The results of our investigation revealed that swine population in Vojvodina region is enzootically infected with MA, and that infection was detected in six different animal species, sporadically or in enzootic form. The single most important factor for MA occurrence was the localization of the farm in the high density pig population regions. Poor biosecurity measures to prevent entry of the virus, and lack of appropriate measures to stop the spreading of the infection within the herd were also idenifyed. The direct contact with pigs, or ingestion of raw and poorly cooked swine products was the estimated route of infection for all other affected animals except three dogs.
\end{abstract}

Key words: Aujeszky's disease, routes of infection, biosecurity 


\section{Introduction}

Aujeszky's disease (Morbus Aujeszky, MA), a serious and highly contagious infection of pigs is caused by alphaherpesvirus, Aujeszky's disease virus (ADV) also designated as Suid Herpesvirus I (Gerdts et al., 1999). Pig is the only natural host for ADV, which accounts for its ability to be subclinically and latently infected (Kluge et al., 1999). Infection of swine herds with ADV can result in substantial costs to pork producers due to increased risks of abortion and preweaning mortality in suckling piglets with occurence of nervous signs and mortality rate often reaching 100\% (Prodanov et al., 2007). Other common farm animals that the virus infects are cattle, sheep, dogs, cats and on the rare occasion horses (Kluge et al., 1999). Several countries that have successfully eradicated the disease by implementing the recommended measures declared MA free status, while others are still in the process of eradication (Panseart and Morrison, 2000). In some Eastern European countries MA eradication is carried out in the framework of the nation-wide eradication programme, while in the others the main goal is to reduce economic losses caused by MA (Medveczky et al., 2000). Today's world swine industry characterised by a great deal of trade and pig movements, requires the implementation of preventive and biosecurity measures to avoid introduction of diseases to the farms (Casal et.al., 2007).

The purpose of this investigation was to estimate epizootical status of Vojvodina Province concerning MA occurrence in different domestic and wild life species, the possible routes of infection and spreading the disease. The role of various biosecurity measures in prevention and control of MA outbreaks was also studied.

\section{Materials and Methods}

The data for this research were taken from: Epizootiological Reports of Ministry of Agriculture, Forestry and Water Management, Statistical Year Book of Serbia. Also, historical, clinical and epizootiological data were obtained through questionnaire that was sent to swine farm owners, practicing veterinarians, veterinary inspectors and regional epizootiologists. Four main topics appeared in the questionnaire: 1) structure of a farm, 2) vaccination status 3) clinical outbreaks in the past ten years 4) biosecurity measures. The applied on spot research methods included: epidemiological and clinical evaluation as well as pathomorphological examination. Laboratory work was also carried out and encompassed: viral isolation (on the susceptible cell culture, PK-15) of tissues originating from the MA suspicious animals and serological testing by serum neutralization test (SNT). 


\section{Results and Discussion}

According to a Statistical Yearbook of Serbia in 2009 the estimated total number of pigs in Vojvodina province was 1.364.000. About $70 \%$ of pig production is operated by small familly farms with less than 50 sows and backyard pig holders. All large commercial farms with more than 500 sows operated in a farrow-to-finish system. Aujeszky's disease is mandatory notifiable disease in Serbia. The number of the cases occurring per year is reported to O.I.E. On large farms of industrial type MA control is based on the surveillance and vaccination with live attenuated vaccines. The main goal of vaccination is to reduce economic loses caused by clinical episodes of MA. The control of the disease in endemic countries is based on compulsory vaccination with attenuated live vaccines of the entire swine population (Casal et al., 2004). However, vaccination for clinical purposes has not been successful in preventing the spread of the virus under field conditions (Leontides et al., 1994). To prevent losses due to clinical illness, vaccination against Aujeszky's disease on an individual herd level is widely practiced (Stegeman et al., 1995). Pigs from small farms (with a few exceptions) and backyard stocks in Vojvodina are not vaccinated.

We investigated 9 large commercial farms for biosecurity measures and managemant practices. Seven of these nine farms suffered MA outbreaks in last 10 years. Also we observed 12 small familly farms ( 20 sows) and 21 individual pig holder (1-3 sows) for biosecurity measures applied. The results of our investigation revealed that on 2 of 9 large farms sheep were raised within farm yard «to keep the grass cut», in six the presence of dogs and cats was detected, and in all but one there was no prevention for pigeon entrance. All the farms provided boots and clothes for the visitors but showering was compulsory only at one farm. A sanitary ford was present in all farms but its maintenance was deficient, since in nither farm except one there was no schedueled plan for changing disinfecting solution, or it was changed only when gets dirty or «when it rains». When epizootical situation of particular risk arise (e.g. outbreak of classical swine fever) than special attention is payed to disinfection baths. Four large farms were buyng replacements from other farms in Serbia, and three of them were apllying the quarantine and controling the source of the animals. The remaining 5 farms were bying only imported breeding pigs with 30 days quarantine and serological testing. Perimetral fence was surrounding all the large farms, but in some it was in poor condition. Rodent and insect control is generally well applied at all large farms. All the noted biosecurity measures and management practices in small and individual pig holdings are generally lacking or are inconsistently applied. In densely pig populated areas appropriate biosecurity measures, coupled with good producing practice are crucial to prevent introduction and within farm spread of MA. 
The epizootical investigation revealed that during the period 2000-2010 the outbreaks of MA were recognized on the territory of 13 municipalities in Vojvodina. During the past ten years infection was diagnosed in seven different animal species: pigs, dogs, cats, cattle, sheep, donkey and one badger (Table 1). The largest number of recognised cases appeared in the municipalities of Central Backa region, in which the most dense pig population was situated. A higher density of pigs increases MA transmission owing to more frequent contacts between the pigs (Bouma et al., 1993). The virus, however, may also be introduced by area spread, which includes: interherd movement of other animal species, people, vehicles, several materials and air (Kluge et al., 1999).

Table 1. Municipalities in Vojvodina with AD outbreaks and animal species affected

\begin{tabular}{|l|l|l|l|}
\hline Year & Municipality & Husbandry & Animal species \\
\hline 2000 & Novi Sad & farm 1 & s \\
\hline 2001 & Becej & farm & s \\
\hline 2001 & Vrbas & hunting-ground & ba \\
\hline 2002 & Novi Sad & farm 2 & s \\
\hline 2002 & Žitiste & individual & s, d, c, b, sh \\
\hline 2002 & Secanj & farm & s \\
\hline 2002 & Pancevo & individual & d \\
\hline 2002 & Novi Becej & individual & s, d, c, b, do \\
\hline 2002 & S.Mitrovica & individual & s, b, sh, d, c \\
\hline 2003 & Novi Sad & individual & c \\
\hline 2005 & Sombor & individual & d \\
\hline 2005 & Becej & individual & d \\
\hline 2005 & Zabalj & individual & s \\
\hline 2005 & Becej & individual & c \\
\hline 2007 & Sr.Mitrovica & individual & d, s \\
\hline 2007 & Temerin & farm 1 & s \\
\hline 2007 & Sr. Mitrovica & small farm & s \\
\hline 2008 & Temerin & farm 2 & s \\
\hline 2009 & Vrbas & farm & s \\
\hline 2010 & Sr. Mitrovica & individual & s,d,c \\
\hline 2010 & Temerin & farm 1 & s \\
\hline 2010 & Zrenjanin & individual & d \\
\hline
\end{tabular}

Legend: s-swine, d-dog, b-bovine, c-cat, sh-sheep, do-donkey, ba-badger

In our investigation single most important factor in a biosecurity program appeared to be a location of the farm. Herds located in areas with a high pig population face a bigger challenge in preventing ADV entry than those herds located in areas with a low pig population (Stegeman et al., 1995). Individually vaccinated herds in Vojvodina are surrounded by non-vaccinated or poorly vaccinated herds and backyard stocks. Such surrounding herds create pockets of susceptibility which can serve as reservoirs of ADV. The capability of aerosol transmission and ability of ADV to travel relatively long distances in the air given 
appropriate environmental conditions has been well documented (Christensen et al., 1990). Epidemiological investigation of the MA outbreaks in large commercial farms and small familly farms revealed that in four out of nine cases the purchesing of replacement animals was the source of infection. The introduction of new animals on the farm is considered the major risk factor for MA and replacements are thought to be the most important cause of the introduction of new disease (Casal et al., 2007). Therefore, the obligatory quarantine measures and serological testing should be conducted when purchasing breeding animals (Dosen et el., 2002). The ADV infection was detected on seven large swine farms of industrial type, out of which six were involved in vaccination program with live attenuated vaccines against $A D$. Vaccination failure on these farms was probably due to irregular vaccination of the sows and lack of boosters for piglets and gilts.

Also, for spreading the infection of significant importance were displacement of latently infected breeding sows, gilts and boars from large farms to individual producers. The observation that clinical Aujeszky's disease was diagnosed in only seven large farms during the past ten years indicates that infections were subclinical in most of the herds. According to Dosen et el. (2002) MA infection is present in the most swine farms in Vojvodina. The average MA seroprevalence of unvaccinated breeding back yard pigs was estimated at $32.72 \%$ (Pusic et al., 2009) suggesting that swine population in Vojvodina province is enzootically infected with MA virus. Apparently, vaccination usually induces sufficient clinical protection, but does not minimize the spread of ADV (Stegeman et al., 1995). During past decade enzootic MA with multiple species affected occurred in municipalities of Zitiste, Novi Becej and Sremska Mitrovica. The routine of keeping pigs mixed with other animal species on the same pasture poses a significant risk factor of spreading the infection. Feeding animal waste products and slurry to pigs is prohibited in Serbia. Nevertheless this practice still exists in back yard farming, and was a route of introduction of infection in two investigated outbreaks. MA in herbivorous animals was always connected to close contact with pigs on the pasture or while keeping different animal species and pigs whithin same premises. Aujeszky's disease virus infection among sheep housed together with pigs was also described by Jacobs et al. (1997).

In carnivors infection was contracted most often through the ingestion of raw meat, offals and bones of pigs that succumbed the disease or were latently infected. Beside ingestion, direct contact with pigs was a second most important source of infection for dogs and cats. In three dogs the documented source of infection was feeding raw sheep offals after compulsory slaugter. 


\section{Conclusion}

The swine population in Vojvodina region is enzootically infected with ADV. Individually vaccinated herds are surrounded by non-vaccinated or poorly vaccinated herds and backyard stocks. Such surrounding herds create pockets of susceptibility which can serve as reservoirs of ADV. Occasionally infection was diagnosed in different domestic and wild life species, but the source of infection for those species were almost in all cases pigs. Voluntary vaccination with live attenuated non g-E deleted vaccines precludes the serodiagnosis of infected pigs, thus making eradication efforts impossible. Nevertheless, quitting of vaccination on some of the large farms in the region with the high density pig population without implementation of strict biosecurity measures is hazardeous. The biosecurity and management practices in backyard herds are generally lacking, which makes them a possible threat for large farms. As Aujeszky's disease became discriminatory factor at the international pig market, it is important to establish regulations regarding disease control and a national or regional Aujeszky's disease eradication program.

\section{Acknowledgment}

Research was financed by the Ministry of Education and Science, Republic of Serbia, project TR 31084.

\section{Epizootiološke karakteristike Aujeskijeve bolesti u Vojvodini i biosigurnosni rizik}

\section{Pušić, J. Prodanov-Radulović, R. Došen, I. Stojanov, D. Stojanović, T. Petrović}

\section{Rezime}

Aujeskijeva bolest (Morbus Aujeszky, pseudorabies) je akutna virusna zarazna bolest većeg broja domaćih i divljih životinja. Uzročnik oboljenja je alfaherpes virus 1. Smatra se jednom od najznačajnijih infektivnih bolesti koje ugrožavaju svinjarsku proizvodnju i ograničavaju mogućnost trgovine svinjama i njihovim proizvodima. Kod ostalih vrsta životinja oboljenje je akutnog toka sa fatalnim ishodom. $\mathrm{U}$ radu su po prvi put, prikupljeni i sistematizovani epizootiološki podaci o pojavi Aujeskijeve bolesti (MA) na teritoriji Vojvodine u periodu od 2000-2010 godine. Epizootiološki podaci prikupljani su iz većeg broja izvora: epizootiološki izveštaji Ministarstva poljoprivrede, vodoprivrede i 
šumarstva, statistički godišnjaci Republike Srbije, upitnici poslati veterinarskim inspektorima, terenskim veterinarima kao i podaci dostavljeni od strane regionalnih epizootiologa. Takođe, znatan deo informacija prikupljen je i direktnim epizootiološkim nadzorom na terenu, koji je obuhvatao uzimanje anamnestičkih podataka, klinički i patomorfološki pregled, kao i virusološka i serološka ispitivanja. Cilj rada je bio da se ustanovi raširenost i učestalost pojavljivanja Aujeskijeve bolesti kod pojedinih vrsta životinja, putevi prenošenja i širenja infekcije i mogućnost primene različitih biosigurnosnih mera u suzbijanju i sprečavanju pojave oboljenja. Rezultati ispitivanja ukazuju da je virus uzročnik Aujeskijeve bolesti enzootski prisutan u populaciji svinja u Vojvodini, a da je infekcija dokazana kod još šest različitih vrsta životinja: goveda, ovaca, pasa, mačaka, magarca, jazavca. U ispitivanom periodu enzootije Aujeskijeve bolesti registrovane su na sedam svinjarskih farmi industrijskog tipa. Pojava MA na farmama svinja bila je povezana pre svega sa lokalizacijom $u$ regionima sa gustom populacijom svinja, ali i nepoštovanjem biosigurnosnih mera za sprečavanje unošenja infekcije kao i njenog daljeg širenja unutar same farme. Kod svih ostalih životinjskih vrsta osim jazavca ustanovljeno je da su bile u direktnom kontaktu sa svinjama ili hranjene nedovoljno termički obrađenim svinjskim proizvodima osim u slučaju tri psa.

\section{References}

BOUMA A., DE YONG M.C.M. (1993): Feasibility of eradication of pseudorabies virus by means of vaccination. Proc. $6^{\text {th }}$ annual meeting of the Dutch Society for the Veterinary Epidemiology and Economics (A.R.W. Elbers, ed.), Boxtel; 31-43. CASAL L., DE MANUEL A., MATEU E., MARTIN M. (2007): Biosecurity measures on swine farms in Spain:Perceptions by farmers and their relationship to current on-farm measures. Prev.Vet. Med., 82, 138-150.

CASAL L., PLANASDEMUNT L.L., VARO J.A., MARTIN M. (2004): The use of different vaccination schedules for sows to protect piglets against Aujeszkys disease. J. Vet. Med. B, 51, 8-11.

CHRISTENSEN L.,S., (1990): Evidence of long distance airborne transmission of Aujeszkys disease virus. Vet. Rec., 127, 19, 471-474.

DOŠEN R., GAGRČIN M., PRODANOV JASNA, LALIĆ M. (2002): Neki epizootiološki momenti kod Aujeskijeve bolesti. Savremena poljoprivreda, 51, 3-4, 269-271.

GERDTS,V., JONS A., METTENLEITER T. (1999): Potency of experimental DNA vaccine against Aujeszkys disease in pigs. Vet. Microbiol., 66, 1-13.

JACOBS L., MULDER, W. (1997).: Detection of wild type Aujeszkys disease virus by PCR in sheep vaccinated with modified live vaccine strain. Res. in Vet. Sci., 62, 271-274. 
KLUGE J.P., BERAN G.W., HILL H.T., PLATT K.B. (1999): Pseudorabies (Aujeszky's disease). In: STRAW B.E., D'ALLAIRE S., MENGELING W.L., TAYLOR D.J., Disease of Swine, Ed by 8th edition., Blackwell Science, 19, 233246.

LEONTIDES L. (1994): Factors associated with circulation of Aujeszky's disease virus in fattening herds of an intensively vaccinated area of the Northern Germany. Prev. Vet. Med., 20, 63-78.

MEDVETZKY I. (2000): Current epizootiological status of the Eastern European countries for Aujeszkys disease. Vet. Res., 31,155-156.

PANSEART M.B., MORRISON M., (2000): Challenges of the final stages of the ADV eradication programm. Vet. Res., 31, 141-145.

PRODANOV J., DOŠEN R., PETROVIĆ T., STOJANOV I, PUŠIĆ I. (2007): Aujeskijeva bolest prasadi na sisi. Zbornik radova IX regionalno savetovanje iz kliničke patologije i terapije životinja, Palić-Beograd, Fakultet Veterinarske medicine.

PUŠIĆ I., ĐURIČIĆ B., DOŠEN R., PRODANOV J., PETROVIĆ T., BURSAĆ V., UROŠEVIĆ M. (2009): Evaluation of the presence of specific antibodies against Morbus Aujeszky virus in unvaccinated swine in Vojvodina province. Biothechnology in Animal Husbandry, 25, 5-6, 887-893.

STEGEMAN A. (1995): Pseudorabies virus eradication by area-wide vaccination is feasible, In: PhD, University of Utrecht, The Netherlands, 125-138. 